\title{
OSNUTEK NOVEGA ZAKONA O VISOKEM ŠOLSTVU IN LOGIKA KAPITALIZMA Financiranje zasebnega na račun javnega šolstva
}

\section{POVZETEK}

Prispevek analizira enega glavnih elementov prestrukturiranja, ki ga v visoko šolstvo vnaša predlagani osnutek novega ZViS. Nanaša se na statusno izenačevanje zasebnih fakultet z javnimi, da bi se tako dokončno legitimiralo njihovo javnoproračunsko financiranje, s tem pa prečrpavanje že tako okleščenih sredstev od javnih $k$ zasebnim šolskim zavodom.

Ključne besede: ZViS, kapitalizem, izobraževanje, zasebne fakultete

THE 2013-2014 HE REFORM DRAFT AND THE LOGIC OF CAPITALISM: PUBLIC FUNDING OF PRIVATE SCHOOL ENTERPRISES AT THE EXPENSE OF PUBLIC UNIVERSITIES - ABSTRACT

The article takes as its point of analysis the new draft of the HE education reform bill, which aims to throw the doors of public universities wide open to corporate agendas. One of many such corporate moves the new proposal supports and legitimizes includes making private schools equal in status with public ones in order to ensure their state funding at the expense of public universities.

Keywords: HE bill, capitalism, education, private faculties

Izr.prof.dr. Lilijana Burcar, Filozofska fakulteta Univerzev Ljubljani, lilijana.burcar@guest.arnes.si 


\section{UVOD}

Osnutek novega Zakona o visokem šolstvu, proti kateremu je študentska organizacija Iskra ob podpori visokošolskih sindikatov 16. aprila 2014 v Ljubljani pripravila protestni shod, med drugim prinaša dokončno legalizacijo financiranja zasebnih fakultet iz javnega proračuna, uvedbo šolnin na raven rednega dodiplomskega študija na javnih univerzah ter nadaljnjo prekarizacijo učiteljske delovne sile ter komercializacijo pedagoškega in znanstvenega dela, kar se v slednjem primeru najbolj izrazito kaže z uvedbo tako imenovanih odcepljenih podjetjih (ZViS, 2014). Osnovni cilj zakona je dokončno izstradati javno visoko šolstvo - s tem pa drastično skrčiti njegov vsebinski razpon in kakovost na eni strani ter dostopnost na drugi - in ga tako predvsem v celoti odpreti komercializaciji in prestrukturiranju v skladu z interesi zasebnega kapitala. Slednjemu je skupna težnja po ustvarjanju novih pridobitniških tržnih niš na račun krčenja, izčrpavanja in siromašenja že tako okrnjenega minimalnega javnega dobrega. Zato ni presenetljivo, da so akterke in akterji študentskega protesta aprila 2014 proti novemu ZViS v njem prepoznali enega od drobcev tektonskih razsežnosti celostnega napada na obstoječi sistem že skrčenih pravic ter svoje zahteve proti šolninam in privatizaciji visokega šolstva vezali tudi na zahteve po ohranitvi tega, kar nam je v 20 letih od uničenja socializma še ostalo od skupne pokojninske blagajne in zdravstva.

Komentarji, ki so se pojavljali v medijsko komajda zaznanih javnih razpravah, so se osredotočili predvsem na problematiko uvajanja šolnin, iz tega izhajajočega strukturnega omejevanja dostopnosti študija in nadaljnjega razslojevanja prebivalstva. Kot dopolnilo tej razpravi se pričujoči prispevek posveča enako problematični, vendar širše spregledani in zamolčani tematiki. ${ }^{1}$ Gre za statusno izenačevanje zasebnih fakultet $\mathrm{z}$ javnimi, da bi se legitimiralo njihovo javnoproračunsko financiranje. Slednje poteka na račun odvzemanja javnoproračunskih sredstev javnemu visokemu šolstvu, kar ni naključje, temveč sestavni del logike kapitala in same privatizacije visokega šolstva. Osnutek novega ZViS pri tem nastopa kot vrh piramide: deluje kot nevaren presedan, za katerega se na videz zdi, da je omejen zgolj na visoko šolstvo. Vendar strukturne spremembe, ki jih vnaša $v$ organizacijo in pomen visokega šolstva, delujejo kot oblika privajanja prebivalstva na domnevno neizogibnost in nujo privatizacije izobraževalnega sistema kot celote. Statusno izenačevanje zasebnih fakultet $\mathrm{z}$ javnimi kot tudi zasebnih vrtcev in srednjih ter osnovnih šol z javnimi zavoljo legitimacije njihovega javnoproračunskega financiranja je samo prvi korak v nizu zakonsko podprtih sprememb, s katerimi se bo v bližnji prihodnosti upravičila nadaljnja privatizacija, s tem pa dokončna razgradnja tudi srednješolske in osnovnošolske javne mreže (na primer $\mathrm{z}$ uvajanjem tako imenovanih vavčerjev in čarterskih šol).

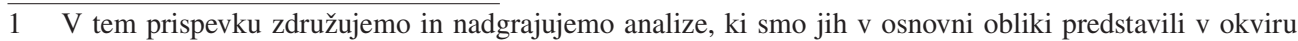
javnih nastopov proti privatizaciji visokega šolstva. Gre predvsem za referate, manifeste, intervjuje in strnjene razčlembe, predstavljene v okviru Akademske solidarnosti (oktober 2012), v Sobotni prilogi Dela, zagrebškega Biltena in ne nazadnje tudi na povabilo urednika Šolskega polja. 


\section{ZVIS IN KONTEKST KAPITALISTIČNE DRŽAVE}

Za razumevanje narave zakona je potrebno razumevanje širšega konteksta, v katerega se osnutek umešča in ki ga strukturno podpira. Pri tem ne gre spregledati, da je to prvi zakon, ki je eksplicitno napisan povsem v skladu z navodili evropskih in globalnih kapitalističnih centrov, za katerimi stojijo Svetovna banka, OECD in Svetovna trgovinska organizacija. V teh dokumentih, ki usmerjajo privatizacijo šolstva in ki jih na ravni EU od leta 1991 uradno uteleša Memorandum o visokem izobraževanju, na države EU pa prek Evropske komisije prenašata Maastrichtski sporazum in Lizbonska pogodba, izobrazba ni več obravnavana kot pravica, izobraževanje pa ne več kot del javnega dobrega. Namesto tega je izobraževanje definirano in obravnavano kot vrsta storitve, s čimer je avtomatično prestavljeno v na novo ustvarjeno ali razširjeno polje tržnih dejavnosti. Temeljni namen ni več sistematično proizvajanje kakovostnega in vsem dostopnega znanja, temveč zasebnega dobička peščice posameznikov in mednarodnih korporacij. Tako je tudi v osnutku ZViS zapisano, da je izobraževalni prostor odprt mednarodnim korporacijam, ${ }^{2}$ odnosno njihovim podjetniško-šolskim podružnicam kot tudi podružnicam tujih nominalno javnih univerz. ${ }^{3}$ Pri tem o izobraževanju govori kot obliki storitve ali storitvene dejavnosti, o znanju pa kot vrsti blaga oziroma tržnega produkta.

$\mathrm{V}$ tem dokumentu gre $\mathrm{v}$ prvi vrsti za legalno in strukturno vodeno preoblikovanje šolstva in univerze $\mathrm{v}$ eno od storitvenih industrij in s tem tržnih dejavnosti, kar pomeni ključni konceptualni preobrat v razumevanju izobrazbe, njene dostopnosti in vsebine. S tem ko je

2 Zasebna šolska podjetja, njihove korporativne izpostave ali pa druge vrste članic zakon opisuje $\mathrm{z}$ navidezno nevtralno sintagmo »mednarodna zveza univerz«, za katero v 15. členu pravi:

Mednarodno zvezo univerz s sedežem v Republiki Sloveniji na podlagi pisnega sporazuma ali pogodbe ustanovita vsaj ena univerza, [...], ki ima akreditirane študijske programe na vsaj treh področjih po ISCED klasifikaciji [...], in vsaj ena univerza s sedežem zunaj Republike Slovenije, akreditirana v državi, kjer ima sedež. Skupaj s prej opredeljenima univerzama so lahko ustanoviteljice mednarodne zveze univerz tudi druge univerze, druge zveze univerz ali univerzitetne mreže, visokošolske in raziskovalne organizacije s sedežem v Republiki Sloveniji ali zunaj nje. (poudarjen poševni tisk)

9. alineja 144. člena še določa načine financiranja, in sicer prek šolnin, višino katerih zasebna šolska podjetja določajo samostojno (posamezniki jim »plačujejo tolikšno šolnino, kot jo je mednarodna zveza univerz določila za državljane Republike Slovenije in ostalih članic Evropske unije«). Hkrati ne gre spregledati, da so šolninam navkljub tudi te javno-zasebne univerze upravičene do lokalnih subvencij, saj 5. alineja 15. člena pravi, da »mednarodna zveza univerz s sedežem v Republiki Sloveniji za svoje delovanje prejema sredstva iz posebne proračunske postavke v proračunu Republike Slovenije«.

3 Gre za novoustanovljene podružnice tujih nominalno javnih in uglednih univerz, ki izpad svojih javnoproračunskih sredstev $\mathrm{v}$ matični državi nadomeščajo, 1., s povečevanjem vpisnih mest za tuje študente in študentke na matičnih ustanovah. Te uvrščajo v posebno kategorijo »tujih « študentov prav zato, da bi jim lahko zakonito zaračunale vsaj še enkrat višjo šolnino kot pa »domačim « študentom, in, 2., z ustanavljanjem podružnic $\mathrm{v}$ drugih državah, zlasti na novo ustvarjeni periferiji Evrope, z izrecnim namenom uvajanja šolnin in komercializacije programa, da bi se na račun prečrpavanja sredstev s periferije nadomestil izpad javnoproračunskih sredstev, potrebnih za nemoteno delovanje matične univerzitetne ustanove na Zahodu, zlasti v ZDA, Veliki Britaniji in Franciji. Pri tem zahodne in le še nominalno javne univerze višino šolnin na svojih izpostavah v tujini določajo in izkoriščajo glede na reputacijo, ki jo gradijo v svojem imperialističnem centru in ki zato nastopa kot sestavni del trženja univerze kot razpoznavno prestižne in zaželene tržne znamke v na novo konstruirani periferiji (Reisberg in Rumbley, 2014; Kleypas in McDougall, 2012; Coulson, Roberts in Taylor, 2015). 
izobraževanje postavljeno za eno od storitev, ki naj bi si jo bilo mogoče pridobiti individualno in domnevno povsem neovirano na trgu, ne glede na dejanske finančne zmožnosti posameznikov in posameznic ter obstoječe strukturne omejitve, je izbrisano pojmovanje izobraževanja in znanja kot temeljne človeške pravice in kot sestavnega dela univerzalno dostopnega ali razpoložljivega javnega dobrega (Leher, 2009, str. 129). Ta zasuk v definiciji, kot je bilo že zapisano v podobnem kontekstu, pa pravzaprav pomeni, da kapitalistična država samo sebe razreši odgovornosti, ki naj bi jo imela do svojih državljank in državljanov pri zagotavljanju splošno dostopne izobrazbe, saj ta zahteva svoj davčni delež tudi od lastnikov kapitala. Hkrati pa si kapitalistična država prav na ta način tudi omogoči časten umik od financiranja javnega izobraževalnega sistema v korist financiranja zasebnega šolstva in drugih zasebnih projektov v obliki javno-zasebnih partnerstev, ki se poslej še izdatneje lepijo na javno šolstvo (Burcar, 2012, str. 230).

Širši kontekst, v katerega se umešča zakon, je sistem poglobljenega izkoriščanja in $\mathrm{s}$ tem strukturno vodenega prečrpavanja skupno ustvarjenih sredstev in dohodka $\mathrm{k}$ ozkemu sloju vse bogatejših. Te strukturno vodene spremembe se v Sloveniji (podobno pa tudi v drugih postsocialističnih državah nekdaj skupnega prostora) kažejo med drugim v še bolj drastičnem zniževanju davka na kapitalski dobiček, ${ }^{4}$ odpravi progresivne davčne lestvice leta $2006,{ }^{5}$ zniževanju prispevnih stopenj delodajalcev za

4 Ta je z že tako nizkih 25 odstotkov v zadnjem desetletju upadel na 17 odstotkov in se bo do konca leta 2015 predvidoma znižal na 15 odstotkov. Kaj to pomeni v praksi, je razvidno denimo iz naslednjega konkretnega primera: Radio Slovenija je decembra 2013 napovedal, da je Henkel-Zlatorog, katerega zasebni prevzemni lastnik je leta 1990 postalo avstrijsko podjetje, v tekočem letu ustvaril 236 milijonov evrov prihodka, od tega 26 milijonov evrov čistega dobička. Na tem mestu se je novica tudi končala, pri čemer je temeljno vprašanje ostalo zabrisano, in sicer, kam se je v resnici stekel ves ta dobiček, ki so ga pravzaprav ustvarili mezdno podplačani delavci, vključno z zaposlenimi v komerciali kot tistimi na morebitnih razvojnih delovnih mestih. Če predpostavljamo, da gre za dobiček pred obdavčitvijo in če je davčna stopnja na kapital 17 odstotkov, osnovni izračun hitro pokaže, da je od tega skupno ustvarjenega dohodka v javni proračun šlo le štiri milijone in pol evrov, kar 21 milijonov pa je odteklo v nekaj zasebnih žepov v tujino. Zniževanje davka na kapitalski dobiček pospešuje redistribucijo dohodka v roke zgornjega sloja prebivalstva na račun siromašenja preostalih, ki so ta dobiček pravzaprav ustvarili.

5 Progresivna lestvica je le zasilni blažilec pri nepravični redistribuciji dohodka. Njena odprava pomeni, da so prejemniki največjih dohodkov avtomatično prestavljeni v nižji dohodninski razred (na primer z 51-odstotne obdavčitve na 40-odstotno ob dohodkih, ki sicer obsegajo nekaj deset tisoč evrov), večina drugih pa se zaradi krčenja števila vmesnih davčnih razredov kljub bornim dohodkom znajde deloma v istem davčnem razredu kot tisti z največjimi dohodki in deloma v (edinem) razredu tik za njimi. Tako bogatejši plačujejo manj, revnejši pa več dohodnine. To preprosto pomeni, da revnejši z večjimi dohodninskimi obremenitvami delno subvencionirajo izpad dohodnine bogatih, kljub temu pa velika finančna luknja še vedno ostaja nezapolnjena. V času konjunkturne krize je kapitalistična država leta 2013 ponovno uvedla še dodaten, a le začasen 50-odstotni dohodninski razred. Ta zajema le odstotek davčnih zavezancev, saj je spodnji cenzus za letno davčno osnovo za to skupino postavljen kar pri 70 tisoč evrih/69 tisoč evrih (5.880 evrov mesečno) in zato pomeni le 16 milijonov evrov letnega priliva (MMC RTV SLO, 15. november 2014). Tako bogatejši sloji ostajajo še vedno sorazmerno razbremenjeni plačevanja davkov v primerjavi z večino prebivalstva, katerega dohodki se gibljejo na ravni povprečne ali minimalne plače. Seveda je Slovenija zgolj učenka in posnemovalka že preizkušenih populistično-slepilnih prijemov kapitalističnih držav Zahoda. Za Francijo, na primer, avtorja študije AAA ugotavljata, da izredni davčni prispevek v višini štirih odstotkov, ki je bil začasno uveden na dohodke bogatih, če ti presegajo 250 tisoč evrov, deluje kot »prava maškarada«, še posebej, če ga hkrati primerjamo »z ožemanjem nižjih razredov z novimi in novimi varčevalnimi načrti« (Millet in Toussaint, 2014, str. 32). 
socialna zavarovanja od leta 1991 dalje $^{6}$ in v odpravi davka na plače za delodajalce leta 2009. ${ }^{7}$ Obenem se temu nizu ukrepov pridružuje podeljevanje cele vrste nepovratnih javnoproračunskih subvencij ${ }^{8}$ posameznim lastnikom kapitala. To pomeni, da jim v nasprotju z običajnimi državljani ni treba najemati kreditov in $\mathrm{s}$ tem posegati v zaradi znižanih obdavčitev na kapital že tako dodatno povečane in prisvojene dobičke. Ker vse to pomeni, da državni proračun večinoma polnijo le še davki na bolj ali manj nizke mezde slehernikov ${ }^{9}$ in zadolževanje države, ne pa davki na dobiček in druge dohodke lastniške elite, nastajajo vse globlje vrzeli v proračunu. Posledica tega poglobljenega strukturnega prečrpavanja sredstev $\mathrm{k}$ vedno bolj bogatim je sistemsko siromašenje javnega proračuna. To pa avtomatično vodi v zmanjševanje razpoložljivih sredstev za potrebe že tako okleščenega javnega sektorja, med drugim tudi za nemoteno delovanje visokega šolstva. Pri tem so se univerze znašle še pod dodatnim finančnim pritiskom, ki ga je ustvarila kapitalistična država, saj je v preteklih letih nastavila vse potrebne pogoje za razmah zasebnih fakultet in univerz.

6 Podatki ZSSS kažejo, da se je v letih 1993-2013 stopnja delodajalskih prispevkov za obvezno zdravstveno zavarovanje znižala s 7,2 na 6,56 odstotka, stopnja prispevkov za zaposlovanje s 1,7 na le 0,06 odstotka in prispevkov za pokojninsko in invalidsko zavarovanje $s$ 15,42 na 8,85 odstotka. Že slednje po poročanju ZSSS in časopisa Dnevnik kumulativno pomeni izpad 8,1 milijarde evrov samo v obdobju med 1996 in 2010 (Predpostavke). Če pa pogledamo individualni izračun, to pomeni, da »se je višina prispevkov za pokojninsko in invalidsko zavarovanje za delodajalce $\mathrm{v}$ zadnjih dvajsetih letih znižala z 235 na 134,84 evra - tj. za 42 odstotkov. Višina prispevkov za zaposlovanje za delodajalce se je ob isti osnovi v zadnjih dvajsetih letih znižala iz 25,9 na 0,91 evra - ali za nekaj več kot 99 odstotkov « (ZSSS, Slika). Ob že tako nizkih izplačilih ne gre spregledati tudi neizplačanih prispevkov, ki so za pokojninsko in invalidsko zavarovanje decembra 2012 znašali že nekaj več kot 354 milijonov evrov, za zdravstvene prispevke pa 175 milijonov evrov (Slika). Vse to pomeni še enega v vrsti strukturnih ukrepov, ki vodijo v še povečano prisvajanje dobička za lastnike kapitala na račun zniževanja standardov zdravstvenega sistema in standarda upokojenih delavcev. Tako je avgusta leta 2013 »več kot polovica « prejemnikov starostne pokojnine »prejemala starostno pokojnino, nižjo od 600 evrov «, tj. na pragu revščine (ZSSS, Slika), oziroma je novembra 2014 »kar 61 odstotkov upokojencev prejemalo pokojnino, nižjo od 593 evrov, kolikor znaša letni prag tveganja revščine« (STA, 12. januar 2015).

7 Podatki ZSSS kažejo, da je iz te postavke leta 2004 proračun pridobil 472 milijonov, leta 2005 505 milijonov, leta 2008 pa le še 230 milijonov. Samo v zadnjih štirih letih pred odpravo tega davka je skupni znesek znašal »več kot dve milijardi evrov« (ZSSS, Slika). Odprava tega davka pomeni še enega v vrsti strukturnih ukrepov, ki lastnikom kapitala omogoča, da si prisvojijo še večji delež sicer skupno ustvarjenega dohodka.

8 Zgovoren je primer novomeškega Revoza, ki je v celoti v zasebni francoski lasti. Samo v obdobju med 2004 in 2009 je bilo temu zasebnemu podjetju podarjenih vsaj 50 milijonov evrov nepovratnih subvencij (Modic, Poslovni dnevnik, 10. november 2011), leta 2014 pa še 22 milijonov (hkrati pa decembra 2015 v časopisju beremo, da bo Revoz odpustil 450 delavcev). Koliko je to na novo zgrajenih ali pa obnovljenih in nemoteno ter kakovostno delujočih državnih šol in vrtcev?

9 Leta 2013 je 14,4 odstotka državljanov Slovenije živelo pod uradno določenim pragom revščine, v resnici pa ta delež znaša vsaj 25 odstotkov, če odštejemo že okrnjene socialne transferje. Pri tem se je uradno število 220 tisoč ljudi pod pragom revščine iz leta 2006 do leta 2013 povzpelo na 291 tisoč. Na pragu socialne izključenosti pa jih živi več kot 20 odstotkov, kar skupaj pomeni vsaj 410 tisoč ljudi (Statistični urad RS, 11. september 2014). 


\section{UVAJANJE IN ŠIRJENJE ZASEBNIH FAKULTET NA RAČUN SIROMAŠENIA JAVNIH}

Javne razprave in argumentirane reakcije proti novemu zakonskemu predlogu so poudarek dajale večinoma le šolninam, pozabljajoč, da je zajeten del zakona namenjen tudi sistematizaciji obstoja in financiranja zasebnih fakultet. Slednje so v novem zakonu po statusu izenačene $\mathrm{z}$ javnimi fakultetami, ${ }^{10} \mathrm{~s}$ čimer je perfidno upravičen in dokončno legaliziran že vpeljani dvotirni sistem javnega financiranja vseh fakultet, tako javnih kot zasebnih, ustanovljenih v drugi polovici prejšnjega desetletja. To pa neizogibno pomeni, da kapitalistična država že tako osiromašena javnoproračunska sredstva, ki naj bi bila namenjena javnim univerzam, še bolj krči, saj jih javnim univerzam odteguje in jih v obliki podeljevanja koncesij vzporedno preusmerja $\mathrm{v}$ ustanavljanje in izdatno nepovratno sofinanciranje zasebnih fakultet. V novem osnutku zakona, ki vodi v legalizacijo zasebnih visokošolskih ustanov, kapitalistična država tako sama sebi nalaga finančno soudeležbo pri ustanavljanju kot tudi pri nadaljnjem pedagoškem in operativnem vzdrževanju zasebnih fakultet.

Kot kažejo podatki, ki smo jih za potrebe te raziskave dopisno pridobili od finančne službe ministrstva za šolstvo, je zasebnim visokošolskim zavodom na državni ravni vsako leto podeljenih vsaj 10 milijonov evrov. $\mathrm{V}$ resnici gre za veliko večje vsote, saj ti podatki ne zajemajo pritoka sredstev z občinskih in drugih državnih institucij, kot so poleg šolskega še finančno in druga ministrstva. Ker podatki o financiranju zasebnih univerz za obdobje 2008-2013 ne obstajajo v strnjeni obliki ali pa je dostop do njih omejen, na tem mestu predstavljamo podatke, ki se nanašajo na javnoproračunsko financiranje zasebnih fakultet prek ministrstva za šolstvo v obdobju med 2011 in 2014. Že razrez finančnih prilivov iz javnoproračunske podpore ministrstva za šolstvo je dovolj nazoren za razumevanje mehanizmov državnega financiranja zasebnih šol.

Tabela 1: Sredstva za zasebne visoke šole v skladu z Uredbo o javnem financiranju visokošolskih zavodov in drugih zavodov v letu 2011 (vir: ministrstvo za šolstvo po Uradnem listu RS)

- $\quad$ za Fakulteto za informaciiske študije $v$ Novem mestu: 546.924,29 evra

- $\quad$ za Univerzo v Novi Gorici: 2.223.820,62 evra

- za Evropsko pravno fakulteto v Novi Gorici: 1.228.024,41 evra

- za Fakulteto za državne in evropske študije: 963.206,25 evra

- $\quad$ za Fakulteto za uporabne družbene študije v Novi Gorici: 518.434,98 evra

- za Mednarodno fakulteto za družbene in poslovne študije: 1.125.118,04 evra

- $\quad$ za Gea College - Fakulteto za podjetništvo: 457.627,42 evra

- $\quad$ za Visoko šolo za dizajn v Ljubljani: 832.962,17 evra

- $\quad$ za Visoko šolo za tehnologije in sisteme: 369.334,97 evra

10 Retorično izenačevanje zasebnih institucij z javnimi, kot kažejo relevantni deli osnutka, poteka na podlagi pripisovanja javne funkcije ali »javne službe«:

1. str. 35: $\gg$ okviru mednarodnih analiz, ki jih izvajata OECD ali Eurydice, se med javne institucije štejejo tudi tiste zasebne, ki za izvajanje programa večino sredstev pridobijo iz javnega denarja.« Gre seveda za tako imenovano krožno hermetično argumentiranje.

2. 116. (4) člen: »Javna služba se izvaja na javnih univerzah in samostojnih javnih visokošolskih zavodih ter na podlagi koncesije na zasebnih visokošolskih zavodih (javna mreža).« 
- za Visoko šolo za tehnologije polimerov: 355.600,29 evra

- $\quad$ za Visoko šolo za upravljanje in poslovanje Novo mesto: 722.560,89 evra

- $\quad$ za Visoko šolo za varstvo okolja: 518.562,97 evra

- $\quad$ za Visoko šolo za zdravstveno nego Jesenice: 717.234,64 evra

- $\quad$ za Visoko šolo za zdravstvo Novo mesto: 715.481,60 evra

Tabela 2: Višina sredstev ministrstva za šolstvo za zasebne visokošolske ustanove v letu 2012 (v EUR)

\begin{tabular}{|c|c|c|c|c|}
\hline Visokošolski zavod & $\begin{array}{l}\text { Leto } 2012 \text { - } \\
\text { TSF-Z (študijska } \\
\text { dejavnost) } \\
\text { PP } 573710\end{array}$ & $\begin{array}{c}\text { Leto 2012: } \\
\text { Interesna deja- } \\
\text { vnost študentov } \\
\text { PP } 574310\end{array}$ & $\begin{array}{l}\text { Leto 2012: PP } \\
8213 \text { Ustanav- } \\
\text { lianje Evrosredo- } \\
\text { zemske univerze }\end{array}$ & $\begin{array}{l}\text { Leto } 2012 \text { : } \\
\text { Skupai zasebni } \\
\text { visokošolski } \\
\text { zavodi }\end{array}$ \\
\hline Univerza v Novi Gorici & $2.055 .446,77$ & 0,00 & 0,00 & $2.055 .446,77$ \\
\hline $\begin{array}{l}\text { Evropska pravna fakulteta v } \\
\text { Novi Gorici }\end{array}$ & $1.135 .046,05$ & 474,30 & 0,00 & $1.135 .520,35$ \\
\hline $\begin{array}{l}\text { Fakutleta za državne in } \\
\text { evropske študije }\end{array}$ & $890.278,27$ & 385,02 & 0,00 & $890.663,29$ \\
\hline $\begin{array}{l}\text { Fakulteta za uporabne druž- } \\
\text { bene študije v Novi Gorici }\end{array}$ & $479.182,31$ & 174,84 & 0,00 & $479.357,15$ \\
\hline $\begin{array}{l}\text { Mednarodna fakulteta za } \\
\text { družbene in poslovne študije }\end{array}$ & $1.039 .931,11$ & 472,44 & 0,00 & $1.040 .403,55$ \\
\hline $\begin{array}{l}\text { Gea College - Fakulteta za } \\
\text { podjetništvo }\end{array}$ & $422.978,72$ & 0,00 & 0,00 & $422.978,72$ \\
\hline $\begin{array}{l}\text { Visoka šola za dizajn v } \\
\text { Ljubljani }\end{array}$ & $769.895,46$ & 0,00 & 0,00 & $769.895,46$ \\
\hline $\begin{array}{l}\text { Visoka šola za tehnologije } \\
\text { in sisteme }\end{array}$ & $341.371,23$ & 53,01 & 0,00 & $341.424,24$ \\
\hline $\begin{array}{l}\text { Visoka šola za tehnologijo } \\
\text { polimerov }\end{array}$ & $328.676,45$ & 0.00 & 0,00 & $328.676,45$ \\
\hline $\begin{array}{l}\text { Visoka šola za upravljanje } \\
\text { in poslovanje Novo mesto* }\end{array}$ & $667.853,08$ & 148,80 & 0,00 & $668.001,88$ \\
\hline $\begin{array}{l}\text { Visoka šola za varstvo } \\
\text { okolja }\end{array}$ & $479.300,61$ & 128,34 & 0,00 & $479.428,95$ \\
\hline $\begin{array}{l}\text { Visoka šola za zdravstveno } \\
\text { nego Jesenice }\end{array}$ & $662.930,10$ & 152,52 & 0,00 & $663.082,62$ \\
\hline $\begin{array}{l}\text { Visoka šola za zdravstvo } \\
\text { Novo mesto }\end{array}$ & $661.309,79$ & 186,93 & 0,00 & $661.496,72$ \\
\hline Skupaj koncesije & $9.934 .199,95$ & $2.176,20$ & 0,00 & $9.936 .376,15$ \\
\hline $\begin{array}{l}\text { Evrosredozemska univerza } \\
\text { (10.a člen ZViS) }\end{array}$ & 0,00 & 0,00 & $386.696,80$ & $386.696,80$ \\
\hline Skupaj & $9.934 .199,95$ & $2.176,20$ & 386.696 .80 & $10.323 .072,95$ \\
\hline
\end{tabular}

Opomba: sredstva za interesno dejavnost študentov so bila dodeljena vsem visokošolskim zavodom s koncesijo, vendar drugi izplačila niso uveljavljali. Dodeljenih jim je bilo: Univerza v Novi Gorici: 283,65 EUR, Gea College - Fakulteta za podjetništvo 138,57 EUR, Visoka šola za dizajn v Ljubljani 211,11 EUR, Visoka šola za tehnologijo polimerov 53,01 EUR. 
Tabela 3: Višina sredstev ministrstva za šolstvo za zasebne visokošolske ustanove v letu 2013 (v EUR)

\begin{tabular}{|c|c|c|c|c|}
\hline Visokošolski zavod & $\begin{array}{l}\text { Leto } 2013 \text { - } \\
\text { TSF-Z (študijska } \\
\text { dejavnost) } \\
\text { PP } 573710\end{array}$ & $\begin{array}{l}\text { Leto 2013: } \\
\text { Interesna deja- } \\
\text { vnost študentov } \\
\text { PP } 574310\end{array}$ & $\begin{array}{l}\text { Leto 2013: PP } \\
821310 \text { Ustanav- } \\
\text { lianje Evrosredo- } \\
\text { zemske univerze }\end{array}$ & $\begin{array}{l}\text { Leto 2013: } \\
\text { Skupaj zasebni } \\
\text { visokošolski } \\
\text { zavodi }\end{array}$ \\
\hline Univerza v Novi Gorici & $1.961 .156,98$ & 0,00 & 0,00 & $1.961 .156,98$ \\
\hline $\begin{array}{l}\text { Evropska pravna fakulteta v } \\
\text { Novi Gorici }\end{array}$ & $1.082 .977,93$ & 399,88 & 0,00 & $1.083 .377,81$ \\
\hline $\begin{array}{l}\text { Fakulteta za državne in } \\
\text { evropske študije }\end{array}$ & $849.438,42$ & 316,75 & 0,00 & $849.755,17$ \\
\hline $\begin{array}{l}\text { Fakulteta za uporabne } \\
\text { družbene študije v Novi } \\
\text { Gorici }\end{array}$ & $457.200,72$ & 133,88 & 0,00 & $457.334,60$ \\
\hline $\begin{array}{l}\text { Mednarodna fakulteta } \\
\text { za družbene in poslovne } \\
\text { študije }\end{array}$ & $992.226,21$ & 370,13 & 0,00 & $992.596,34$ \\
\hline $\begin{array}{l}\text { Gea Fakulteta - Fakulteta } \\
\text { za podjetništvo }\end{array}$ & $403.575,36$ & 0,00 & 0,00 & $403.575,36$ \\
\hline $\begin{array}{l}\text { Fakulteta za dizajn, samo- } \\
\text { stojni visokošolski zavod, } \\
\text { pridružena članica Uni- } \\
\text { verze na Primorskem }\end{array}$ & $734.577,94$ & 202,13 & 0,00 & $734.780,07$ \\
\hline $\begin{array}{l}\text { Visoka šola za tehnologije } \\
\text { in sisteme }\end{array}$ & $325.711,46$ & 73,50 & 0,00 & $325.784,96$ \\
\hline $\begin{array}{l}\text { Visoka šola za tehnologijo } \\
\text { polimerov }\end{array}$ & $313.599,03$ & 52,50 & 0,00 & $313.651,53$ \\
\hline $\begin{array}{l}\text { Visoka šola za upravljanje } \\
\text { in poslovanje Novo mesto }\end{array}$ & $637.216,57$ & 161,00 & 0,00 & $637.377,57$ \\
\hline $\begin{array}{l}\text { Visoka šola za varstvo } \\
\text { okolja }\end{array}$ & $457.313,59$ & 116,38 & 0,00 & $457.429,97$ \\
\hline $\begin{array}{l}\text { Fakulteta za zdravstvo } \\
\text { Jesenice }\end{array}$ & $632.519,42$ & 163,63 & 0,00 & $632.683,05$ \\
\hline $\begin{array}{l}\text { Fakulteta za zdravstvene } \\
\text { vede Novo mesto }\end{array}$ & $630.973,44$ & 171,50 & 0,00 & $631.144,94$ \\
\hline Skupaj koncesije & $9.478 .487,07$ & 2.161 .28 & 0,00 & $9.480 .648,35$ \\
\hline $\begin{array}{l}\text { Evrosredozemska univerza } \\
\text { (10.a člen ZViS) }\end{array}$ & 0,00 & 0,00 & $388.985,00$ & $388.985,00$ \\
\hline Skupaj & 9.478 .487 .07 & 2.161 .28 & 388.985 .00 & $9.869 .633,35$ \\
\hline
\end{tabular}


Tabela 4: Višina sredstev ministrstva za šolstvo za zasebne visokošolske ustanove v letu 2014 (v EUR)

\begin{tabular}{|c|c|c|c|c|}
\hline Visokošolski zavod & $\begin{array}{l}\text { Leto } 2014- \\
\text { TSF-Z (študijska } \\
\text { dejavnost) } \\
\text { PP } 573710\end{array}$ & $\begin{array}{l}\text { Leto 2014: } \\
\text { Interesna deja- } \\
\text { vnost študentov } \\
\text { PP } 574310\end{array}$ & $\begin{array}{l}\text { Leto 2014: PP } \\
8213 \text { Ustanav- } \\
\text { ljanje Evrosredo- } \\
\text { zemske univerze }\end{array}$ & $\begin{array}{l}\text { Leto } 2014: \\
\text { Skupaj zasebni } \\
\text { visokošolski } \\
\text { zavodi }\end{array}$ \\
\hline Univerza v Novi Gorici & $1.932 .928,00$ & 230,14 & 0,00 & $1.933 .158,14$ \\
\hline $\begin{array}{l}\text { Evropska pravna fakulteta v } \\
\text { Novi Gorici }\end{array}$ & $1.067 .389,49$ & 387,13 & 0,00 & $1.067 .776,62$ \\
\hline $\begin{array}{l}\text { Fakulteta za državne in } \\
\text { evropske študije }\end{array}$ & $837.211,57$ & 223,00 & 0,00 & $837.434,57$ \\
\hline $\begin{array}{l}\text { Fakulteta za uporabne } \\
\text { družbene študije v Novi } \\
\text { Gorici }\end{array}$ & $450.619,75$ & 142,72 & 0,00 & $450.762,47$ \\
\hline $\begin{array}{l}\text { Mednarodna fakulteta } \\
\text { za družbene in poslovne } \\
\text { študije }\end{array}$ & $977.944,06$ & 341,64 & 0,00 & $978.285,70$ \\
\hline $\begin{array}{l}\text { Gea Fakulteta - Fakulteta } \\
\text { za podjetništvo }\end{array}$ & $397.766,28$ & 111,50 & 0,00 & $397.877,78$ \\
\hline $\begin{array}{l}\text { Fakulteta za dizajn, samo- } \\
\text { stojni visokošolski zavod, } \\
\text { pridružena članica Uni- } \\
\text { verze na Primorskem }\end{array}$ & $724.004,39$ & 199,81 & 0,00 & $724.204,20$ \\
\hline $\begin{array}{l}\text { Visoka šola za tehnologije } \\
\text { in sisteme }\end{array}$ & $321.023,15$ & 57,09 & 0,00 & $321.080,24$ \\
\hline $\begin{array}{l}\text { Visoka šola za tehnologijo } \\
\text { polimerov }\end{array}$ & $309.085,07$ & 67,79 & 0,00 & $309.152,86$ \\
\hline $\begin{array}{l}\text { Visoka šola za upravljanje } \\
\text { in poslovanje Novo mesto }\end{array}$ & $628.044,45$ & 166,80 & 0,00 & $628.211,25$ \\
\hline $\begin{array}{l}\text { Visoka šola za varstvo } \\
\text { okolja }\end{array}$ & $450.731,00$ & 121,31 & 0,00 & $450.852,31$ \\
\hline $\begin{array}{l}\text { Fakulteta za zdravstvo } \\
\text { Jesenice }\end{array}$ & $623.414,91$ & 164,13 & 0,00 & $623.579,04$ \\
\hline $\begin{array}{l}\text { Fakulteta za zdravstvene } \\
\text { vede Novo mesto }\end{array}$ & $621.891,18$ & 159,67 & 0,00 & $622.050,85$ \\
\hline Skupaj koncesije & $9.342 .053,30$ & $2.372,73$ & 0,00 & $9.344 .426,03$ \\
\hline $\begin{array}{l}\text { Evrosredozemska univerza } \\
\text { (10.a člen ZViS) }\end{array}$ & 0,00 & 0,00 & $388.985,00$ & $388.985,00$ \\
\hline Skupaj & $9.342 .053,30$ & $2.372,73$ & $388.985,00$ & $9.733 .411,03$ \\
\hline
\end{tabular}


Kot je tudi vsaj delno razvidno iz tabel, zasebne fakultete niso le neposredno upravičene do koncesij oziroma nepovratnih subvencij iz javnega proračuna, ampak tudi do sredstev, ki naj bi bila namenjena vzdrževanju njihove infrastrukture, in do sodelovanja na javnih razpisih. Prav to pa jih enači z javnimi univerzami ne le pri neposrednem pridobivanju koncesij/finančnih subvencij, ampak tudi pri posrednem črpanju javnoproračunskih sredstev v postavkah, ki se nanašajo na sofinanciranje raziskovalnih programov, štipendij, publikacij, raziskovalnih programov in študentskih dejavnosti (Burcar, 2012, str. 233). Takšno legalno izenačevanje prinaša denimo 140. člen:

Sofinanciranje se nanaša na internacionalizacijo, mobilnost, mednarodne projekte, ustanavljanje podjetij, tehnoloških parkov, novih študijskih in raziskovalnih področij, inovativne pristope $\mathrm{k}$ študiju in na podobne cilje, ki prispevajo k razvoju visokega šolstva. Ker je glavni cilj v tem delu razvoj visokega šolstva, so lahko izvajalci (oz. se lahko prijavijo na razpis) poleg - poglavitnih - javnih visokošolskih zavodov tudi zasebni zavodi in druge fizične ali pravne osebe zasebnega prava, ki izpolnijo pogoje za pridobitev javnih sredstev.

Kot kaže tudi praksa v tujini, gre v obeh primerih posrednega ali neposrednega javnoproračunskega financiranja za namenski prenos sredstev iz javnega $v$ zasebni sektor, s tem pa za izčrpavanje javnega visokega šolstva na račun izdatnega in nepovratnega financiranja ter posledične strukturne krepitve zasebnih in profitno naravnanih univerz in fakultet kot podjetniških ustanov.

Zato je javno financiranje zasebnih fakultet treba obravnavati v širši luči strukturne krepitve zasebnega na račun javnega, pri čemer ne gre spregledati celostne slike preusmerjanja javnoproračunskih sredstev v zasebne izobraževalne institucije, saj te poleg visokošolskih ustanov zajemajo tudi vse več zasebnih osnovnih, srednjih in glasbenih šol. Če se namreč ozremo širše po celotni vertikali izobraževalnega sistema, je zasebnim osnovnim, srednjim in glasbenim šolam, ki so večinoma v lasti Cerkve, letno na ministrstvu za šolstvo dodeljenih vsaj 12 milijonov evrov javnoproračunskih sredstev. Kot je razvidno iz tabele, priložene v Prilogi (Tabela 3), država zasebnim osnovnim, srednjim in drugim šolam, ki so bile ustanovljene pred letom 1996, v celoti plačuje obratovalne stroške: gre za stoodstotno pokritje osnovnih materialnih stroškov in plač učiteljev, »ne pa tudi stroškov investicij« (Pirc, Mladina, 4. december 2008). Šolam, ki so bile ustanovljene po letu 1996, pa država »krije 85 odstotkov obratovalnih stroškov« (prav tam). Vse to koristi predvsem RKC, ustanoviteljici in lastnici največjega števila zasebnih šol. Prav njenim šolam je na ravni predfakultetnega izobraževanja letno namenjenih skoraj 8,5 milijona evrov javnega denarja, pa čeprav je RKC ena izmed največjih upraviteljic in lastnic zasebnega kapitala v svetu. Podatki, pridobljeni od finančne službe ministrstva za šolstvo, kažejo, da je država zasebnim cerkvenim šolam samo v letu 2011 namenila 8.564.644 evrov, leta 2012 8.238.406 evrov in leta 20139.337 .589 evrov. Skupna vsota nepovratnih finančnih 
sredstev, dodeljenih cerkvenim šolam, je tako samo v obdobju 2011-2013 znašala okoli 26 milijonov evrov. ${ }^{11}$

Če torej seštejemo vsa javnoproračunska sredstva, ki jih letno vsem zasebnim izobraževalnim institucijam v obliki nepovratnih finančnih injekcij namenja zgolj ministrstvo za šolstvo, ta znesek znaša vsaj 22 milijonov evrov. V triletnem obdobju je to skupaj kar 66 milijonov evrov. To pa še zdaleč ni zanemarljivo malo tako na kratki kot na dolgi rok, saj ta vsota pomeni izpad prav tolikšnih letnih sredstev za javno šolstvo in vsaj 220 milijonov na desetletni ravni. Pri tem je treba upoštevati, da nekatere zasebne šole ob nepovratnih javnoproračunskih subvencijah ali tako imenovanih koncesijah zaračunavajo tudi šolnine. Podatki za Euro šolo, denimo, kažejo, da to zasebno izobraževalno podjetje, ki prejme kar 380 tisoč evrov državnih subvencij letno, zaračunava še šolnino v višini 2.495 evrov na učenca letno in vpisnino v višini 200 evrov (osebna korespondenca s tajništvom šole, 14. januar 2015).

\section{DRŽAVNO SPONZORIRANE ZASEBNE ŠOLE IN LOGIKA PROFITA}

Kapitalistična država ustanavljanje in sofinanciranje zasebnih fakultet v javnosti opravičuje z izgovorom, da naj bi bile te stroškovno bolj učinkovite, v prostor izobraževanja pa naj bi vnesle več izbire. Tudi v novem osnutku zakona je ta strukturni premik, ki legalizira financiranje zasebnih fakultet iz javnega proračuna, s tem pa stekanje javnoproračunskih sredstev $\mathrm{v}$ dividende in zasebne roke peščice lastnikov teh institucij, predstavljen kot oblika težnje, $\mathrm{s}$ katero naj bi se povečala »svoboda študija in izbire študijskih programov«; uvedba zasebnih fakultet pa naj bi pomenila obliko »skrbi za kvaliteto in učinkovitost študija« (3. člen), saj naj bi slednje dopolnjevale vrzeli, ki jih s svojimi programi ne pokrivajo javni zavodi in fakultete. ${ }^{12}$

11 Zato tudi novice, ki jo je 7. januarja 2015 lansiral medijski portal RTV SLO, ni mogoče obravnavati drugače kot prikrivanje dejstev. Sporen je že naslov, ki pravi »Za šole še 290.000 evrov«, saj v luči aktualnih rezov pri sredstvih, namenjenih javnim osnovnim in srednjim šolam, bralstvo navaja k pomirjajočemu mišljenju, da gre za denar, nakazan vsem šolam, prvenstveno prav javnim, kajti izraz šola še vedno nastopa kot kroven in nevtralen izraz za večinsko še vedno javne šole. Prvi stavek članka pa razkrije, da gre za denar, nakazan zasebnim šolam. Enako sporna je tudi sama ubeseditev sporočila, ki pravi, da je »država za financiranje programov zasebnih šol lani namenila nekaj manj kot 2,8 milijona evrov. Če bi te programe financirali 100-odstotno, bi to pomenilo še [komajda] 290.000 evrov. « Novica torej neprikrito deluje v prid pokrivanja vseh obratovalnih stroškov zasebnih šol, kot da gre za povsem zanemarljiv znesek ob sicer sočasnem odpravljanju plačil učne pomoči in drugih rezih na javnih šolah. Pri tem pa še navaja, da »V Sloveniji osnovnošolski vzgojno-izobraževalni program izvajajo tri zasebne šole« s poudarkom na waldorfski. S tem so potvorjena in zabrisana tri ključna dejstva: da je financiranje zasebnih šol vsaj šestkrat bolj obsežno, da ne gre samo za tri, ampak, kot kažejo tabele ministrstva, za 17 zasebnih šol (ki ne obsegajo samo osnovnošolskega, ampak tudi srednješolski program), in da je od tega sedem cerkvenih in deležnih skorajda 70 odstotkov vseh sredstev.

12 153. člen opravičuje vpeljevanje zasebnih izobraževalnih institucij v klasični neoliberalni maniri kot vrsto dopolnila v sistemu javnega izobraževanja, ki ga po defaultu opredeljuje za pomanjkljivega, kot da tri javne univerze s skupno 56 članicami tega naj ne bi v celoti ali pa kakovostno pokrivale:

(1) Koncesija za izvajanje dejavnosti v visokem šolstvu se lahko podeli (1) samostojnemu visokošolskemu zavodu (v nadaljevanju: koncesionar), kadar država ali samoupravna lokalna skupnost ( $v$ nadaljevanju: koncedent) v okviru javne mreže ne moreta zagotoviti izvajanja dejavnosti $v$ predvidenem obsegu in kakovosti ali kadar ne moreta zagotoviti upravičencem enake dostopnosti do dejavnosti javnih visokošolskih zavodov glede na izkazane potrebe na trgu dela po določenem študijskem programu ali profilu diplomanta. 
A kot kaže dolgoletna praksa $v$ tujini in od vsega začetka uvajanja zasebnih fakultet tudi pri nas, vpeljevanje profitnih izobraževalnih institucij in ustvarjanje umetne tekmovalnosti vodita kvečjemu v nižanje kakovosti študija. Zasebne profitne fakultete lahko nizke obratovalne stroške in s tem velike dobičke dosežejo le tako, da se sistematično izogibajo izvajanju programov, ki so tehnološko in razvojno zahtevni ter zato stroškovno intenzivni, kot sta denimo medicina in strojništvo (Weiler, 2000, str. 337). Namesto tega so te ustanove $\mathrm{v}$ celoti osredotočene na izvajanje stroškovno najmanj obremenjenih programov, denimo na področju ekonomije, menedžmenta, prava, informacijskih in družboslovnih znanosti. Iz tega izhaja zgolj umetna razširitev oziroma podvojitev programov, ki jih izvajajo že javne univerze, zato je za delovanje zasebnih fakultet ključnega pomena, da jim pri naboru študijske populacije pomaga prav država s svojimi strukturnimi posegi. Dotok ustreznega števila študentov jim namreč zagotovi z vzporednim omejevanjem vpisnih mest na študijskih programih javnih fakultet (ponekod v tujini pa z uvedbo tako imenovanih vavčerjev), pri čemer so politiki reduciranja vpisnih mest simptomatično izpostavljene prav humanistične in družboslovne javne fakultete.

Znamenja teh procesov so se pri nas pojavila takoj ob prvem množičnem ustanavljanju zasebnih fakultet po letu 2006 v času prve vlade Janeza Janše, ki je vedno večji poudarek dajala zmanjševanju vloge družboslovnih in humanističnih fakultet ter povečevanju vloge naravoslovno-tehniških fakultet $v$ okviru javnega visokega šolstva. Temu je po takratnem dekretu ministrstva za visoko šolstvo pod vodstvom Jureta Zupana ter v sklopu skrbno plasiranega diskurza o domnevni nepotrebnosti in neuporabnosti humanističnih in družboslovnih programov sledilo od države predpisano zmanjševanje vpisnih mest na družboslovju in humanistiki na javnih univerzah. Hkrati pa so se sočasno ustanavljale zasebne družboslovne in humanistične fakultete, denimo sočasna ustanovitev dveh zasebnih humanističnih/družboslovnih univerz, in sicer Univerze v Novi Gorici s petimi članicami in eno visoko šolo ter Evrosredozemske univerze s sedežem v Piranu. Prav ta vzporedni proces je bil očem širše javnosti prikrit, pri čemer ni šlo za naključje ali paradoks, temveč za jedro logistične operacije z dvojnim učinkom. $S$ preusmerjanjem pogleda na javne fakultete ter domnevno neuporabnost in odvečnost humanističnega in družboslovnega študija je tako lahko ostalo zabrisano dejstvo, da so bile novoustanovljene zasebne in profitno naravnane fakultete, ki naj bi po zagotovilih uradnih predstavnikov ministrstva in zagovornikov privatizacije zagotavljale večjo izbirnost študija, prav okleščene kopije javnih družboslovnih in humanističnih institucij in da so svoj delež študentske populacije pridobile ob pomoči države na račun omejevanja vpisnih mest na javnih fakultetah. Le na račun slabljenja javnega visokega šolstva je bilo mogoče tudi ustvariti umetni primanjkljaj vpisnih mest in tako nastali nevpisani presežek študentske populacije navidezno legitimno preusmeriti z javnih na novonastale družboslovne in humanistične zasebne fakultete. Ta proces seveda ni izum periferne kapitalistične države, ampak gre za povzemanje vzorca, že vzpostavljenega na Zahodu. S tovrstnimi posegi, ki jih legitimira tudi novi zakon, kapitalistična država institucije javnega značaja vse bolj izpodriva ali pa jih postavlja v konfrontacijo z na novo ustanovljenimi zasebnimi, da bi tako poskrbela za uvajanje pridobitniško naravnanih 
dejavnosti in legitimacijo zasebne akumulacije kapitala na račun prečrpavanja javnoproračunskih sredstev v roke lastnikov zasebnih fakultet.

Pri tem, kot smo že poudarili v drugem kontekstu, lahko zasebne in profitno naravnane fakultete tako imenovano stroškovno učinkovitost dosežejo le na račun zniževanja obratovalnih stroškov in tako imenovanih stroškov dela (Burcar, 2012, str. 237). Kot kaže nekajdesetletna praksa v tujini, to pomeni, da sredstev, pridobljenih s koncesijami in šolninami, zasebne fakultete praviloma ne vlagajo $\mathrm{v}$ gradnjo in opremo knjižnic, laboratorijev in druge osnovne infrastrukture, kot so denimo že same zgradbe, kjer naj bi potekala predavanja. Iz tega izhaja rast števila zasebnih fakultet, ki ponujajo (za njih cenejši) študij le na daljavo in brez kontaktnih ur z učiteljem. Prav tako pridobljenih sredstev ne usmerjajo $\mathrm{v}$ zahtevne in finančno ustrezno podprte raziskovalne dejavnosti, ampak se namesto tega $\mathrm{v}$ večini osredotočajo zgolj na rutinsko poučevanje kot tudi preprosto sestavljanje učnih paketov in kurikulov, ki jih patentirajo, da bi jih za plačilo dale v koncesionarno izposojo drugim izobraževalnim institucijam. Prizadevanja tovrstnih zasebnih visokošolskih zavodov, kot potrjuje praksa $\mathrm{v}$ tujini in vse bolj tudi pri nas, so namesto $\mathrm{v}$ zagotavljanje kakovostne izobrazbe usmerjena $\mathrm{v}$ trženje in $\mathrm{s}$ tem $\mathrm{v}$ ustvarjanje univerze kot prepoznavne blagovne znamke, za kar zasebne fakultete in univerze poleg odliva za dividende tudi porabijo največ denarja. Stroške dela pa znižujejo s podplačevanjem zaposlenih, tj. z zaposlitvami za določen in polovičen delovni čas ali pa z delom na honorarno pogodbo, z zaposlovanjem ljudi z nižjo izobrazbo od zahtevane, kar vodi v še dodatno podplačanost, in z visokimi nadobremenitvami minimalnega števila zaposlenih.

Osnutek v 23. členu tako sicer navaja, da je eden od pogojev za ustanovitev visokošolskega zavoda tudi ustrezno število visokošolskih učiteljev in sodelavcev ter znanstvenih delavcev, ki so potrebni za izvajanje študijskega programa. Vendar pa sočasno tudi določa, da je ustanovitvenemu pogoju zadoščeno, če institucija izkazuje vsaj »eno tretjino zaposlenih za polni delovni čas « oziroma v primeru ustanavljanja nove univerze z najmanj 81 pedagoškimi in znanstvenimi delavci, od katerih jih mora biti »vsaj ena tretjina zaposlenih za nedoločen čas«. To pomeni, da osnutek novega zakona legalno omogoča, da je lahko pravzaprav do dve tretjini pedagoških in znanstvenih delavcev zaposlenih po netipičnih pogodbah in da jih ne ščitijo kolektivne pogodbe. To ne nazadnje nakazuje tudi 208. člen, ki pravi, da do odpravnine niso upravičeni delavci, ki so zaposleni za določen čas, kar se v novem žargonu nanaša na prekarne delavce, ki delajo honorarno, denimo na tako imenovanem »projektnem delu«.

Do odpravnine ob prenehanju pogodbe o zaposlitvi za določen čas niso upravičeni delavci, ki jim preneha pogodba o zaposlitvi za dopolnilno delo (če imajo že sklenjeno pogodbo o zaposlitvi za nedoločen čas), delavci, ki imajo pogodbo o zaposlitvi za določen čas sklenjeno za pripravo oziroma izvedbo dela, ki je projektno organizirano, mladi raziskovalci za čas podiplomskega študija za pridobitev doktorata znanosti, kakor tudi v primeru sklenitve pogodbe za določen čas zaradi neizpolnjevanja pogojev za opravljanje dela. 
Ker zasebnim univerzam ni treba skrbeti za financiranje dragih študijskih programov in/ali vzdrževanje lastne infrastrukture ter morebitnih raziskovalnih projektov, saj so ti izdatki preneseni na ramena davkoplačevalcev, jim od tako podarjenih koncesij in zaračunanih šolnin ob hkratni fleksibilizaciji delovne sile ostaja več čistega dobička. $\mathrm{V}$ vseh primerih privatizacije javnega šolstva kot seveda javnega dobrega nasploh gre torej za tipično zasebno akumulacijo kapitala, ki parazitira na podružbljanju stroškov in pozasebljanju dobička.

Na tem mestu tako ni mogoče spregledati vsaj enega od vidikov, ki kaže na medsebojno povezanost uvedbe instituta šolnin s širjenjem tržne logike v izobraževanje, s tem pa erozije javno dostopnega in skupnega dobrega. Uvajanje šolnin je posledica nesprejemljivega krčenja javnoproračunskih sredstev, čemur močno botrujejo najrazličnejši bonusi v obliki nizkega davka na dobiček in nepovratnih subvencij zasebnemu kapitalu, kar smo razčlenili že v uvodu. Uvajanje šolnin in njihovo opravičevanje pa služi tudi širjenju finančnega trga na področje javnega šolstva, saj šolnine oziroma ustvarjanje dolga med šele šolajočo se populacijo pomeni vodo na mlin zasebnemu bančnemu sektorju. S tem se na eni strani ustvari nov trg oderuškega obrestnega kreditiranja in hkrati nov vir finančnega špekuliranja s kreditnimi dolgovi v obliki tako imenovanih derivativov, na drugi pa utišana bodoča populacija že vnaprej zadolženih delavcev. Uvajanje šolnin na javnih univerzah, ki jih osnutek novega zakona širi na dodiplomski študij, pa je tudi strukturna podpora zasebnim fakultetam. Te lahko študentsko populacijo pridobijo in ustvarjajo nadaljnje dobičke od zaračunavanja šolnin le, če so tudi javne univerze tiho podstandardizirane in sprivatizirane in če institut plačevanja šolnin obvladuje tudi javne univerze (Slaughter in Rhoades, 2004). V nasprotnem primeru bi namreč večina študentske populacije ostala na javnih univerzah, zasebne pa bi ostale praznih rok.

Zadnji osnutek tako javnim fakultetam dopušča oziroma nalaga, da ob rednih in neplačljivih študijskih mestih sočasno razpisujejo tudi plačljiva, in sicer v obsegu do 40 odstotkov redno vpisanih in neplačljivih mest na program. Kot kaže praksa v tujini, to preprosto pomeni, da bodo fakultete zmanjševale število rednih neplačljivih študijskih mest na račun zapolnjevanja zgornjega praga plačljivih mest. Že prvi osnutek zakona je izrazito razredno segregacijski, saj določa, da se šolnina zaračuna tistemu delu populacije, ki se zaradi »slabih« študijskih rezultatov ni mogel vpisati na redno razpisana študijska mesta. To pa po navadi zajema študente, ki niso imeli dodatnih možnosti financiranja obšolskih dejavnosti, inštrukcij ali pa so morali zaradi šibkega finančnega zaledja delati prek dijaških in študentskih napotnic in tako niso imeli možnosti za poglobljen študij. Pri vsem tem gre tako za omejevanje dostopnosti študija kot tudi za njegovo podstandardizacijo: če so namreč plače učiteljskega kadra odvisne od pretoka študentov v višji letnik (torej od šolnin), to avtomatično vodi v niŽanje standardov, tj. sprejemanje krajših enosemestrskih predmetov, tečajniške oblike poučevanja in nižanje zahtevnosti, kar je bilo že nastavljeno prav z uvedbo regresivne bolonjske reforme. 


\section{SKLEP}

Procesi in dejstva, ki smo jih razčlenili v prispevku, so še eno od znamenj, ki neoliberalno mantro o »nevmešavanju « države v gospodarstvo in o izstopanju države iz javnega sektorja s poudarkom na individualni odgovornosti posameznika razkriva kot vrsto demagogije par excellence. Nobena država in politika ni ločena od ekonomije in družbeno-političnega polja, saj gre za neločljive podstati sistema, ki tvorijo državo kot tako. Nastop neoliberalnega diskurza tako pomeni, da gre pri kapitalistični državi kvečjemu za odstopanje od minimalnih konsenzov na škodo večjega dela populacije in večanje obstoječih privilegijev vse bogatejše elite, ki izhajajo iz ohranjanja in poglabljanja strukturnih neenakosti. Financiranje zasebnih fakultet na račun nadaljnjega podhranjevanja javnih je eden od vrste primerov, ki kaže, da se pod mantro deregulacije obstoječega družbenega tkiva sočasno izvaja njegova sistemska re-regulacija v še večjo zasebno pridobitniško korist nastavljenih oblastno-lastniških elit. Kapitalistična država s svojimi zakonskimi posegi in sistemsko vodenimi procesi - sestavni del katerih je preusmerjanje in prerazporejanje umetno skrčenih javnoproračunskih sredstev med zasebne akterje - pri tem vseskozi igra ne le aktivno, ampak ključno vlogo.

\section{PRILOGA}

Tabele, iz katerih je razvidna višina sredstev ministrstva za šolstvo za zasebne šole (vrtci, osnovne, srednje, glasbene šole) v letih 2011-2014, vse v EUR.

\section{Legenda}

2

3

Davčna številka

Cerkvene (da/ne)

Obseg financiranja (\%)

Dejavnost osnovnega šolstva

Dejavnost srednjega šolstva

Dejavnost dijaških domov

Dejavnost višjega šolstva

Dejavnost glasbenega šolstva

Dejavnost izobraževanja odraslih

Izobraževanje brezposelnih
11 Učbeniki in učna tehnologija

12 Izobraževanje učiteljev

13 Regresirana prehrana učencev

14 Regresirana prehrana dijakov

15 Brezplačni vrtec za družine, ki imajo v vrtcu hkrati več otrok

16 Subvencije za šolo v naravi

17 Študentski domovi

18 Zmanjševanje izobrazbenega primanjkljaja in svetovanje - ESS 


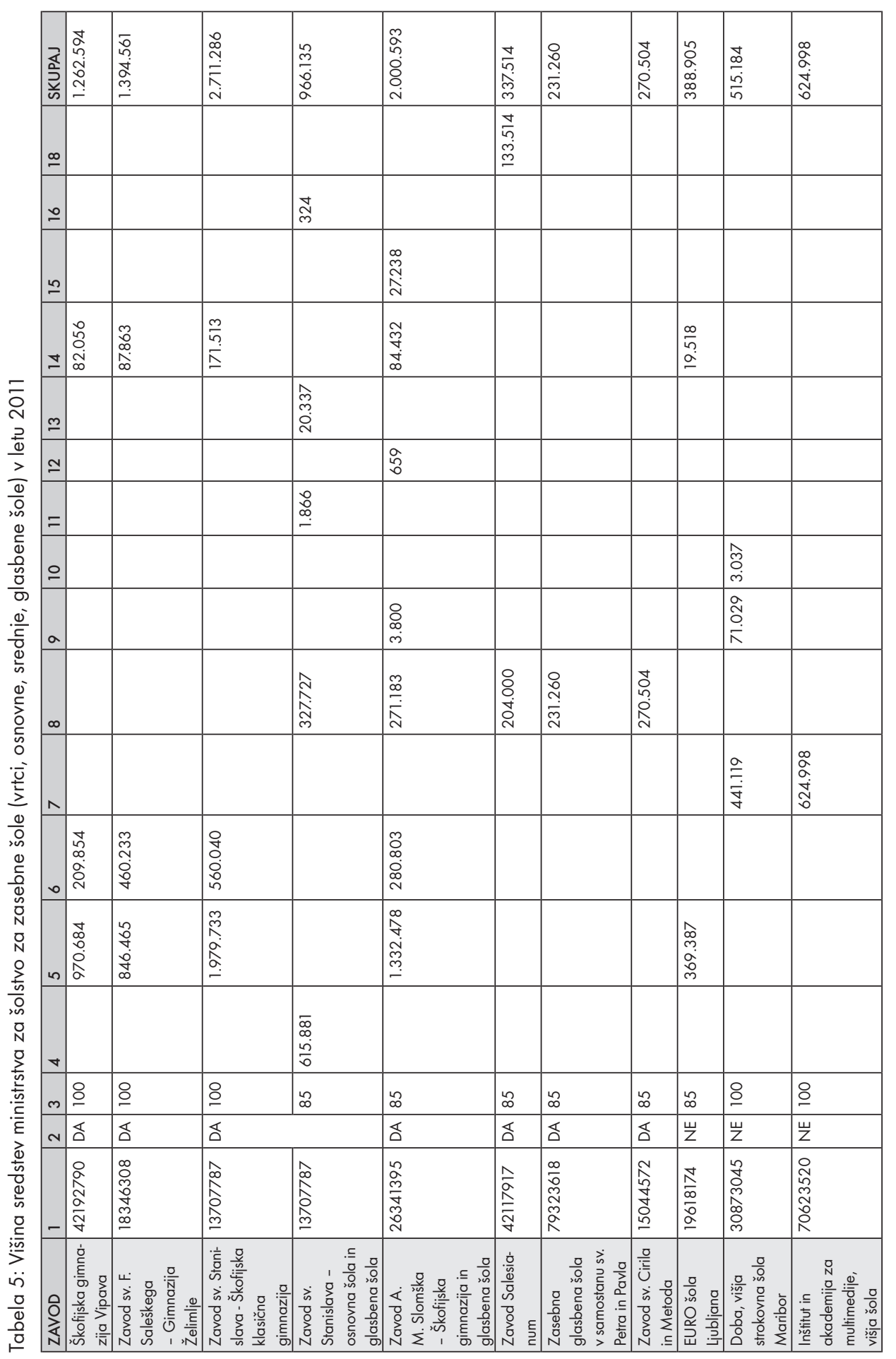




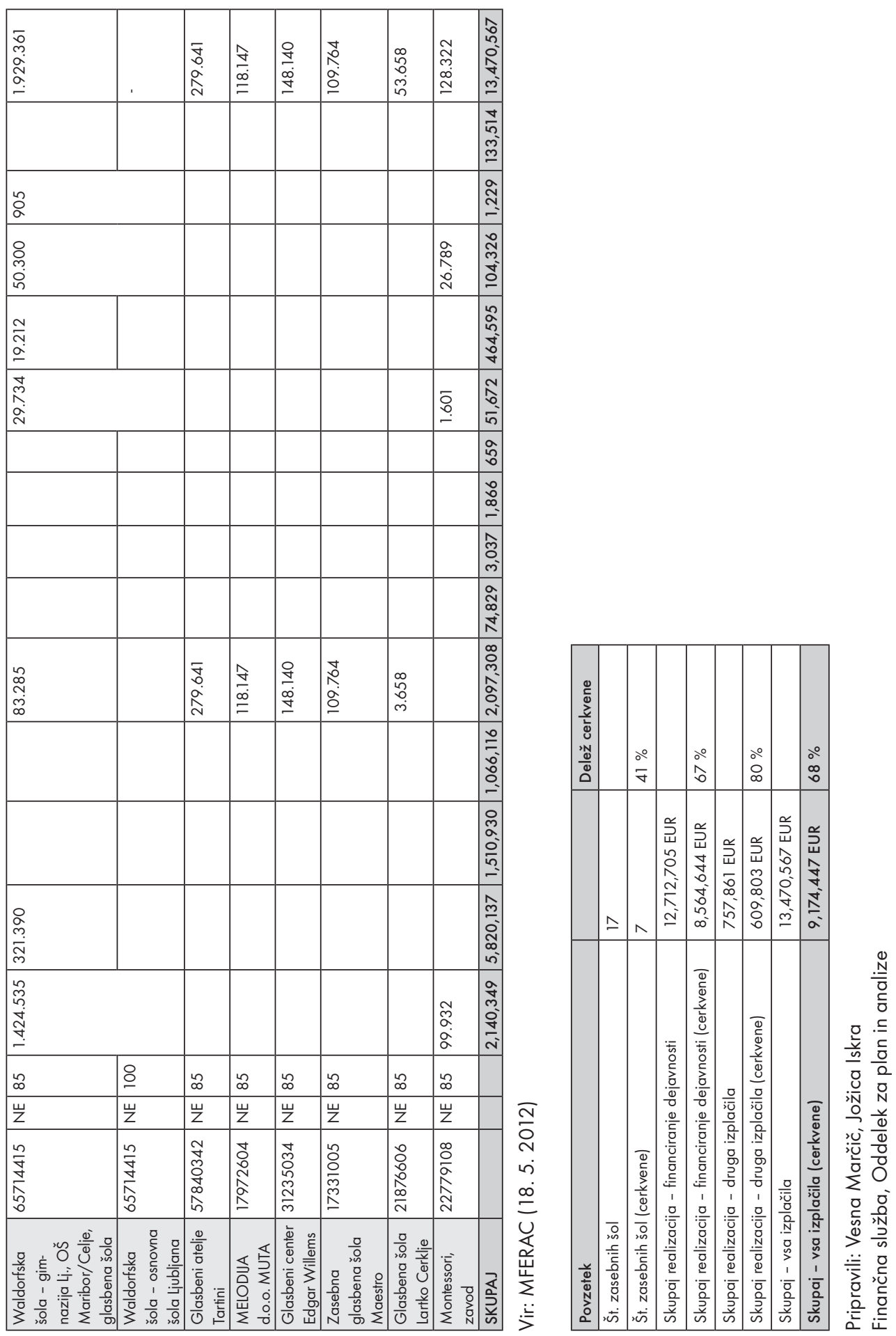




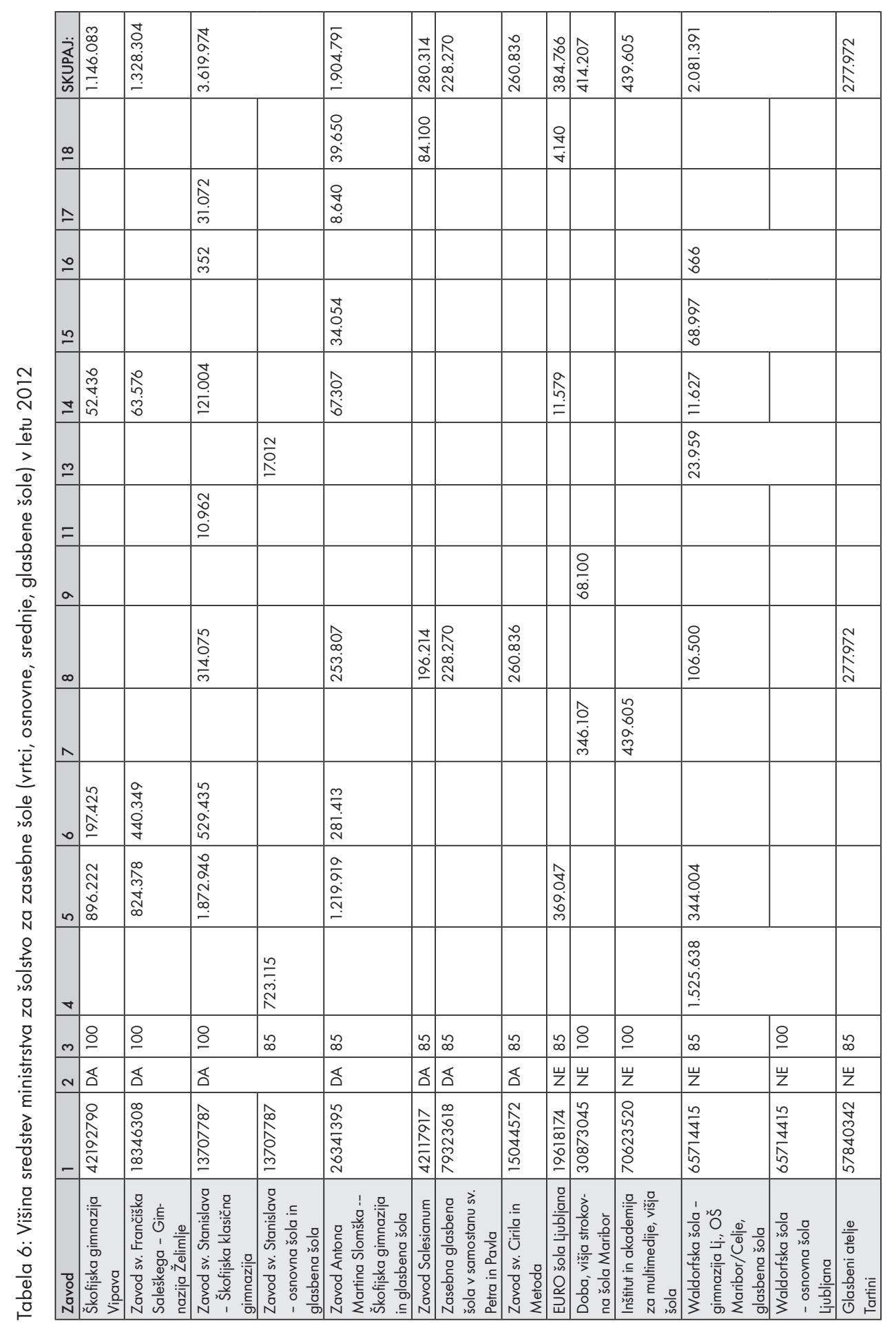




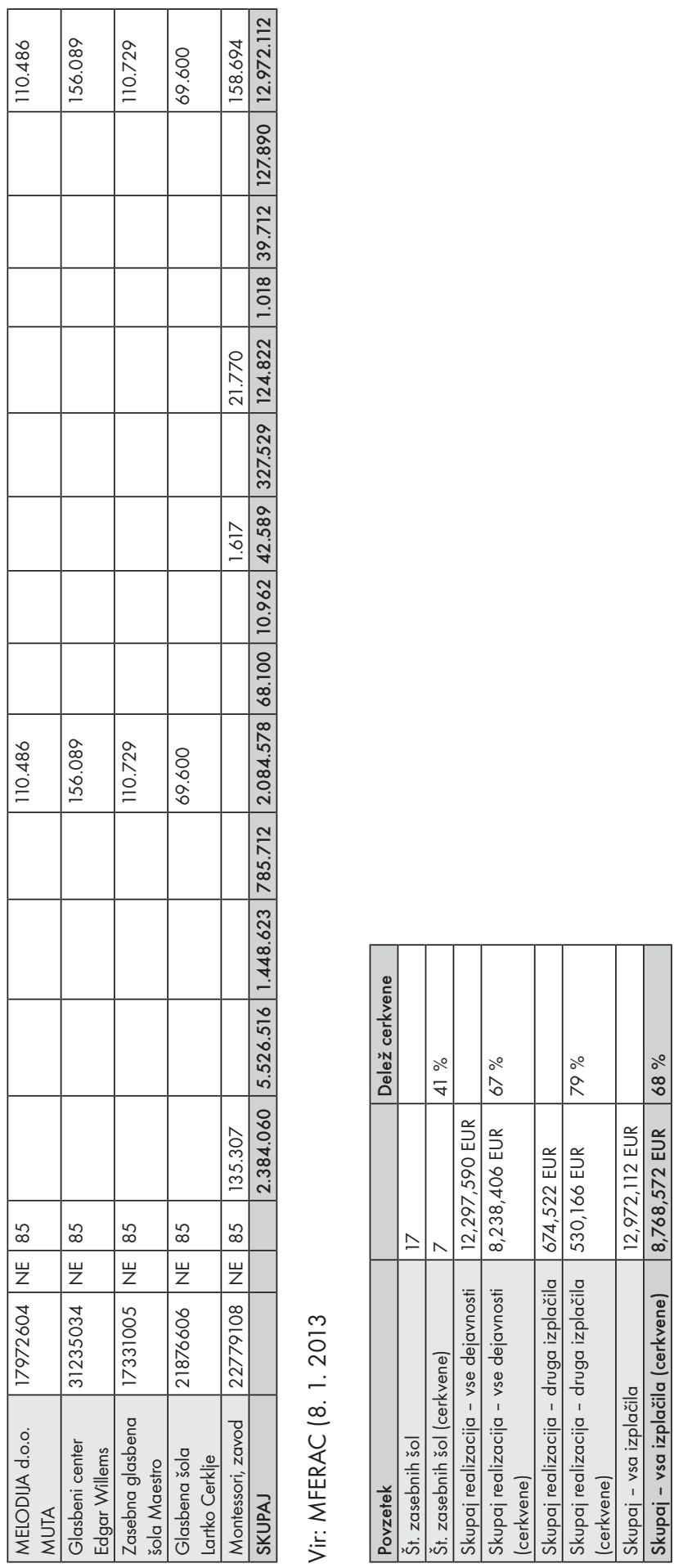




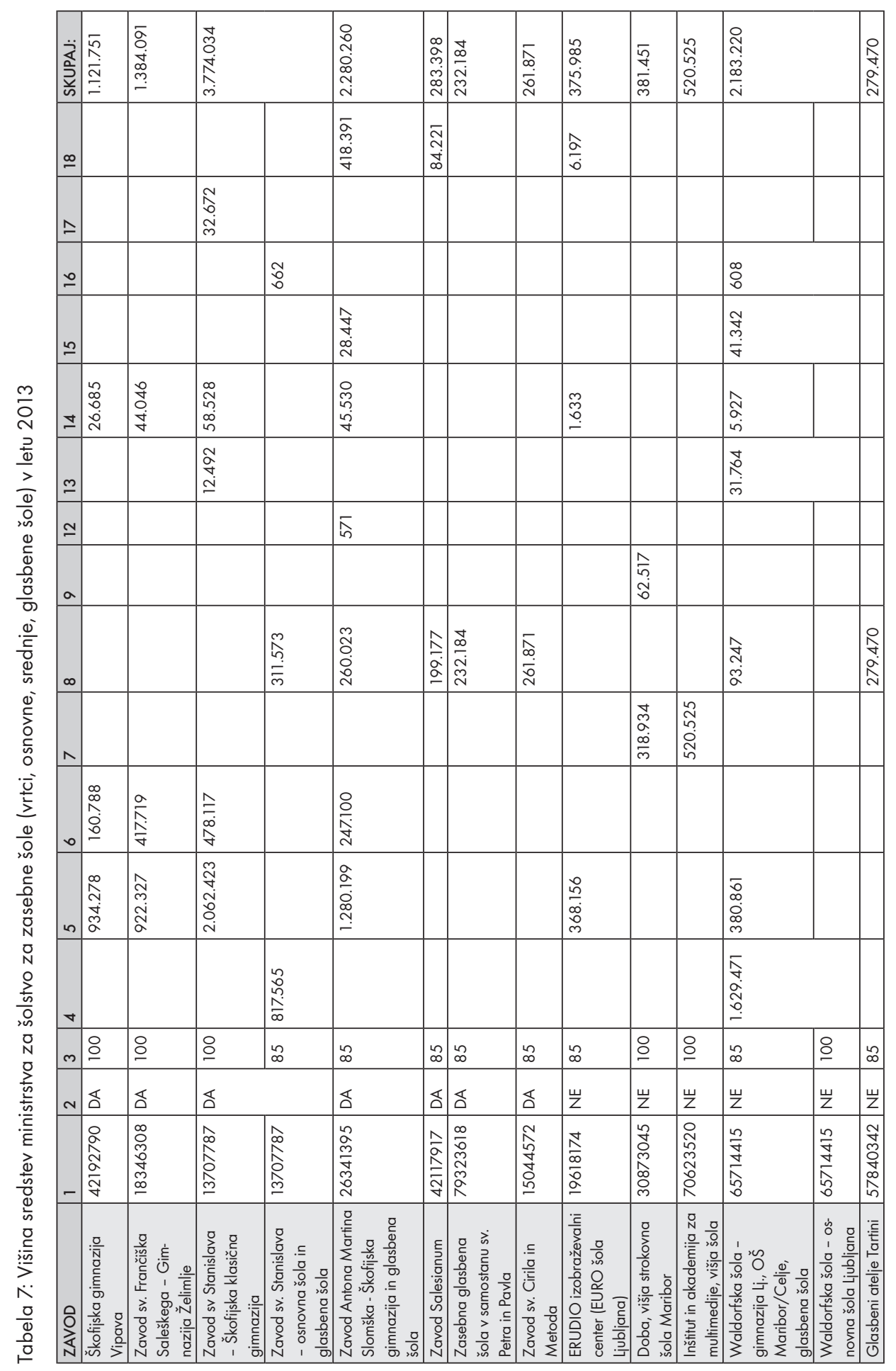



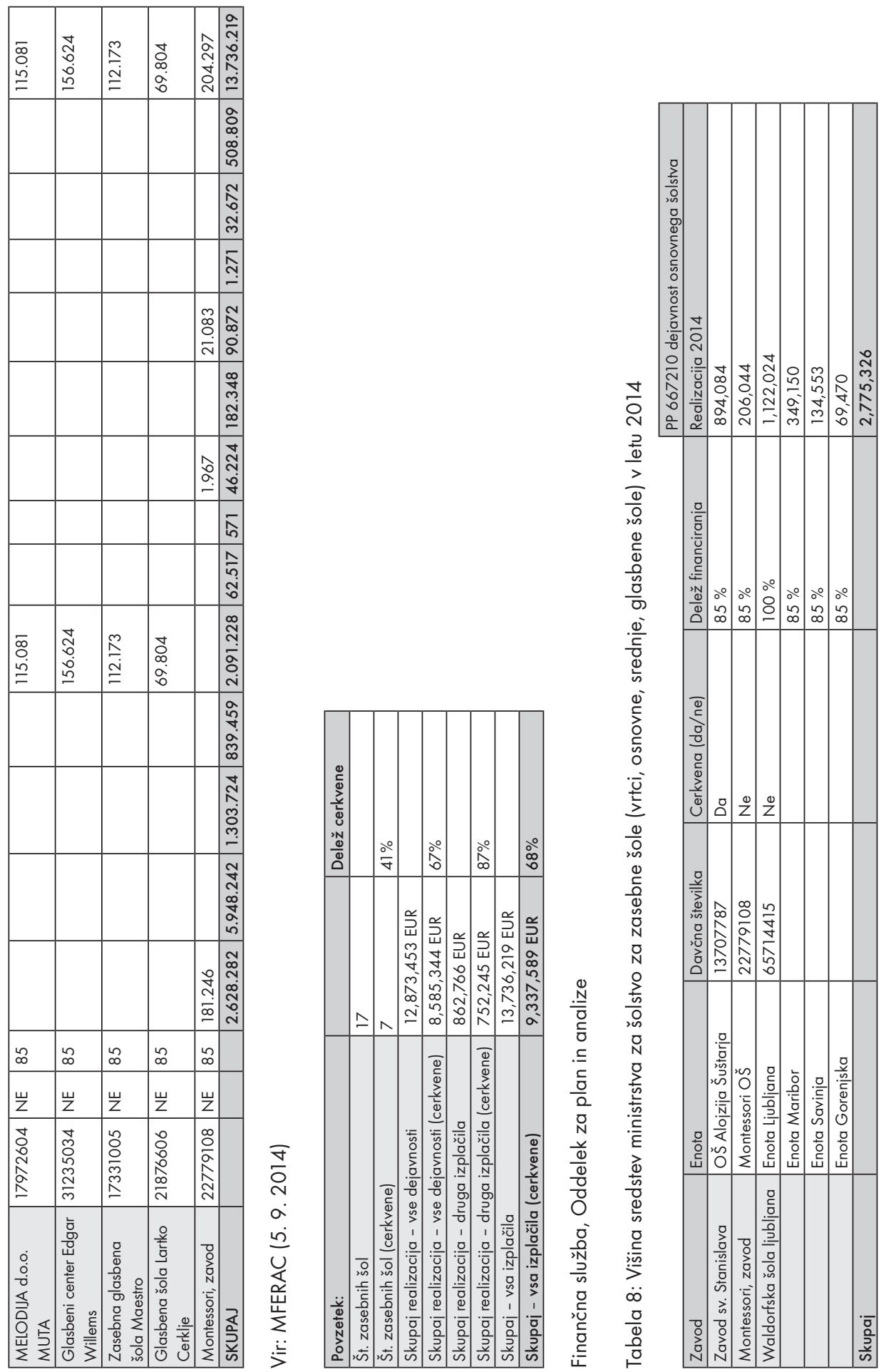

\begin{tabular}{l}
$\frac{0}{0}$ \\
$\frac{1}{5}$ \\
0 \\
$\frac{0}{0}$ \\
$\frac{0}{0}$ \\
0 \\
$\frac{0}{0}$ \\
$\frac{0}{0}$ \\
\hline 0 \\
0
\end{tabular}
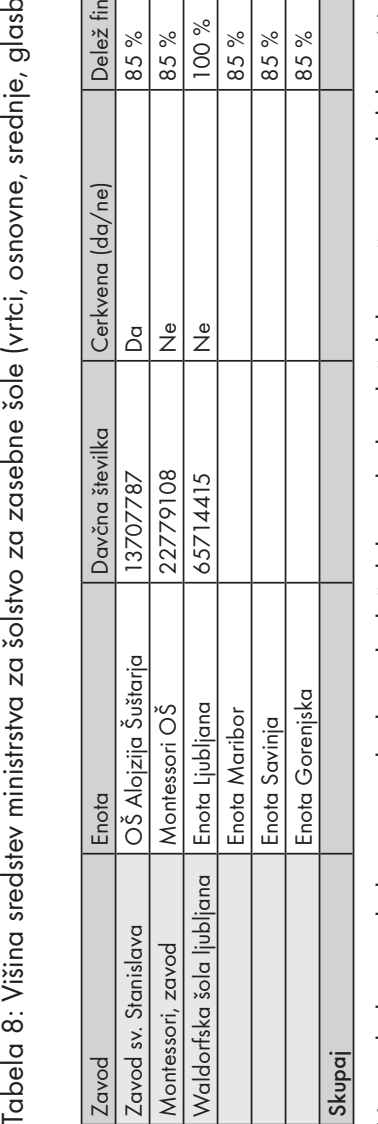

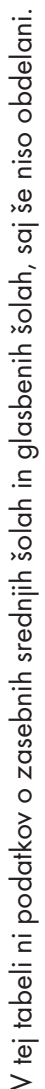




\section{LITERATURA}

Burcar, L. (2012). Privatizacija in korporativizacija javne univerze. Šolsko polje, 23(3-4), 223-274.

Coulson, J., Roberts, P. in Taylor, I. (2015). University Trends: Contemporary Campus Design. New York: Routledge.

Kleypas, K. L. in McDougall, J. I. (2012). The American-Style University at Large: Transplants, Outposts, and the Globalization of Higher Education. Langham; Plymouth: Lexington Books.

Leher, R. (2009). Brazilian Education, Dependent Capitalism: A Classical Marxist Analysis. V D. Hill in R. Kumar (ur.), Global Neoliberalism and Education and its Consequences (str. 127-150). New York in London: Routledge.

Millet, D. in Toiussaint, É. (2014). AAA: revizija, odpis, drugačna politika. Sophia: Ljubljana.

MMC RTV SLO (2014). 50-odstotna dohodnina ostaja. Pridobljeno s http://www.rtvslo.si/.

MMC RTV SLO (2015). Za šole še 290.000 evrov. Pridobljeno s http://www.rtvslo.si/.

Modic, T. (2012). Revoz si obeta 45,5 milijona evrov državne pomoči. Pridobljeno s http://volitve.dnevnik.si/posel/novice/1042486848.

Pirc, V. (2008). Rdeča luč za financiranje zasebnikov. Mladina, 49. Pridobljeno s http://www.mladina. si/45559/rdeca-luc-za-financiranje-zasebnikov/.

Reisberg, L. in Rumbley E. L. (2014). Redefining Academic Mobility: From the Pursuit of Scholarship to the Pursuit of Revenue. Higher Education Dynamics: The Forefront of International Higher Education: A Festschrift in Honor of Philip G. Altbach, 42, 115-126.

Semolič, D. (2015). »Izčrpavanje upokojencev« je nujno ustaviti. Pridobljeno s http://www.dnevnik.si/ slovenija/semolic-izcrpavanje-upokojencev-je-nujno-ustaviti.

Slaughter, S. in Rhoades, G. (2004). Academic Capitalism and the New Economy: Markets, State, and Higher Education. Baltimore: John Hopkins UP.

Zakon o visokem šolstvu, osnutek (2013). Pridobljeno s http://www.mizs.gov.si/si/zakonodaja_in_ dokumenti/predlogi_predpisov/.

Zakon o visokem šolstvu, osnutek (2014). Pridobljeno s http://www.mizs.gov.si/si/zakonodaja_in_ dokumenti/predlogi_predpisov/.

ZSSS (2011). Predpostavke novega pokojninskega zakona - in dejstva o teh predpostavkah. Pridobljeno s www.zsss.si/attachments/.../PREDPOSTAVKE_DEJSTVA_ZPIZ2.doc.

ZSSS (2013). Slika o Sloveniji - Kdo je plačal tranzicijsko zabavo? Pridobljeno s http://www.sindikatzsss.si/attachments/article/1033/KdoJePlacalTranzicijskoZabavo_ZSSS_September2013.pdf.

Weiler, N. H. (2000). States, Markets and University Funding: new paradigms for the reform of higher education in Europe. Compare, 3, 333-339. 